\title{
IMPLEMENTASI SISTEM PAKAR MENDIAGNOSA PENYAKIT PENYAKIT GASTRITIS DENGAN MENGGUNAKAN METODE TEOREMA BAYES
}

\author{
M.Rizky Fadhilah", Ishak, S.Kom., M.Kom ${ }^{* *}$, Puji Sari Ramadhan, S.Kom., M.Kom * \\ * Program Studi Sistem Informasi, STMIK Triguna Dharma \\ ${ }^{* * *}$ Program Studi Sistem Komputer, STMIK Triguna Dharma
}

\begin{abstract}
Abstrak
Gastritis atau lebih dikenal sebagai magh berasal dari bahasa yunani yaitu gastro, yang berarti perut atau lambung dan itis yang berarti inflamasi atau peradangan. Gastritis adalah suatu keadaan peradangan atau peradangan mukosa lambung. Secara histopatologi dapat dibuktikan dengan adanya infiltrasi sel-sel radang pada daerah tersebut. Ada dua jenis gastritis yang terjadi yaitu gastritis akut dan kronik. Pada usia produktif masyarakat rentan terserang gejala gastritis karena dari tingkat kesibukan, gaya hidup yang kurang memperhatikan kesehatan serta stres yang mudah terjadi. Gastritis dapat mengalami kekambuhan dimana kekambuhan yang terjadi pada penderita gastritis tidak mudah untuk dikenali.

Melihat permasalahan tersebut maka diperlukan diagnosa penyakit Gastritis, dengan sebuah sistem yaitu sistem pakar menggunakan metode teoerma bayes. Maka dari itu dirancanglah sebuah sistem aplikasi berbasis dekstop dengan menerapkan metode teoerma bayes dimana nilai kesimpulan akhir dijadikan informasi untuk untuk jenis penyakit gastritis berdasarkan gejala - gejla yang telah dialami .

Adapun hasil dari penelitian ini adalah sebuah aplikasi yang dapat melakukan mendiagnosa penyakit gastrtiis secara sistematis, sehingga dapat dilakukan penanganan ataupun pencegahan yang tepat sesuai dengan hasil dari diagnosanya.
\end{abstract}

Kata kunci : Sistem pakar, teorema bayes, Penyakit Gastritis.

\begin{abstract}
Gastritis or better known as magh comes from the Greek word gastro, which means stomach or stomach and itis which means inflammation or inflammation. Gastritis is a condition of inflammation or inflammation of the gastric mucosa. Histopathologically, it can be proven by the infiltration of inflammatory cells in the area. There are two types of gastritis that occur, namely acute and chronic gastritis. At the productive age, people are prone to gastritis symptoms because of their busyness, lifestyle that does not pay attention to health and stress that easily occurs. Gastritis can recur where the recurrence that occurs in people with gastritis is not easy to recognize.

Seeing this problem, it is necessary to diagnose Gastritis, with a system, namely an expert system using the Bayes Theoerma method. Therefore, a desktop-based application system was designed by applying the Bayes theory method where the final conclusion value is used as information for types of gastritis based on the symptoms that have been experienced.

The results of this study are an application that can diagnose gastritis disease systematically, so that proper treatment or prevention can be carried out in accordance with the results of the diagnosis.
\end{abstract}

Keywords: Expert system, Bayes theorem, Gastritis disease. 


\section{PENDAHULUAN}

Gastritis atau lebih dikenal sebagai magh berasal dari bahasa yunani yaitu gastro, yang berarti perut atau lambung dan itis yang berarti inflamasi atau peradangan. Gastritis adalah suatu keadaan peradangan atau peradangan mukosa lambung. Secara histopatologi dapat dibuktikan dengan adanya infiltrasi sel-sel radang pada daerah tersebut [1]. Ada dua jenis gastritis yang terjadi yaitu gastritis akut dan kronik.

Penyakit gastritis dapat menyerang seluruh lapisan masyarakat dari semua tingkat usia maupun jenis kelamin tetapi dari beberapa survei menunjukkan bahwa gastritis paling sering menyerang usia produktif. Pada usia produktif masyarakat rentan terserang gejala gastritis karena dari tingkat kesibukan, gaya hidup yang kurang memperhatikan kesehatan serta stres yang mudah terjadi.

Gastritis dapat mengalami kekambuhan dimana kekambuhan yang terjadi pada penderita gastritis tidak mudah untuk dikenali. Kondisi gejala yang dialami dari penderita penyakit gastritis pada umumnya sulit untuk dideteksi. Dalam permasalahan ini diperlukan sebuah sistem salah satunya adalah sistem pakar yang dapat mendiagnosa penyakit gastritis pada lambung manusia sehingga dapat dilakukan penanganan ataupun pencegahan yang tepat.

Sistem pakar atau sering disebut dengan expert system merupakan cabang dari artificial intelligence atau kecerdasan buatan yang kinerjanya mengadopsi keahlian dari seorang pakar dan menyimpan pengetahuannya didalam komputer sehingga memungkinkan pengguna dapat berkonsultasi layaknya dengan pakar manusia[2].

Metode teorema Bayes merupakan suatu metode untuk menghasilkan suatu estimasi parameter dengan menggabungkan informasi dari sampel dan informasi lain yang telah tersedia sebelumnya. Disamping itu, Metode Teorema Bayes memberi hasil pendugaan yang lebih baik daripada pendugaan metode klasik [3].

\section{KAJIAN PUSTAKA}

\subsection{Gastritis}

Gastritis merupakan gangguan yang paling sering ditemui dalam praktek sehari-hari karena diagnosis penyakit ini hanya berdasarkan gejala klinis. Penyakit ini sering dijumpai timbul secara mendadak yang biasanya ditandai dengan rasa mual atau muntah, nyeri, pendarahan, rasa lemah, nafsu makan menurun atau sakit kepala. Gastritis yang terjadi di Negara maju sebagian besar dialami usia tua. Hal ini berbeda dengan negara berkembang yang banyak dialami usia muda.

\subsection{Sistem pakar}

Pakar adalah paket hardware dan software yang digunakan sebagai pengambil keputusan atau penyelesaian, yang dapat mencapai level yang setara atau kadang malah melebihi pakar/ahli, pada suatu area yang spesifik atau sempit.

Sistem pakar atau sering disebut dengan expert system merupakan cabang dari artificial intelligence atau kecerdasan buatan yang kinerjanya mengadopsi keahlian dari seorang pakar dan menyimpan pengetahuannya didalam komputer sehingga memungkinkan pengguna dapat berkonsultasi layaknya dengan pakar manusia.

\subsection{Metode Teorema Bayes}

Metode Teorema bayes dikemukakan oleh seorang pendeta Presbyterian inggris pada tahun 1763 yang bernama Thomas Bayes ini kemudian disempurnakan Laplace. Teorema bayes digunakan untuk menghitung probabilitas terjadinya suatu peristiwa berdasarkan pengaruh yang didapat dari hasil observasi. Disamping ini metode bayes memanfaatkan data sampel yang diperoleh dari populasi juga memperhitungkan suatu distribusi awal yang disebut distribusi prior.

Metode Teorema Bayes juga digunakan untuk penelitian lain seperti untuk mendiagnosa penyakit pada tanaman buah citrus [4]. Kemudian juga digunakan untuk mendiagnosa penyakit pada tanaman bougenville [5], juga digunakan untuk mengidentifikasi pecandu narkoba [6]

Teorema Bayes sebuah teorema dengan dua penafsiran berbeda. Dalam penafsiran Bayes, teorema ini menyatakan seberapa jauh derajat kepercayaan subjektif harus berubah secara rasional ketika ada petunjuk baru.

Dalam penafsiran frekuentis teorema ini menjelaskan representasi invers probabilitas dua kejadian. Bentuk teorema bayes evidence tunggal $\mathrm{E}$ dan hipotesa tunggal $\mathrm{H}$.

Probabilitas Bayesian adalah salah satu cara untuk mengatasi ketidakpastian dengan menggunakan Formula Bayes yang dinyatakan sebagai berikut [16]. 


$$
P(H \mid E)=\frac{\mathrm{p}(\mathrm{E} \mid \mathrm{H}) \cdot \mathrm{p}(\mathrm{H})}{\mathrm{p}(\mathrm{E})}
$$

Dimana :

$\mathrm{P}(\mathrm{H} \mid \mathrm{E})$ : probabilitas hipotesa $\mathrm{H}$ jika terdapat evidence $\mathrm{E}$

$\mathrm{P}(\mathrm{E} \mid \mathrm{H})$ : probabilitas munculnya evidence $\mathrm{E}$ jika hipotesis $\mathrm{H}$

$\mathrm{P}(\mathrm{H}) \quad$ : probabilitas hipotesa $\mathrm{H}$ tanpa memandang evidence apapun

$\mathrm{P}(\mathrm{E}) \quad$ : probabilitas evidence $\mathrm{E}$ tanpa memandang apapun

Penerapan teorema bayes untuk mengatasi ketidakpastian, jika muncul lebih dari satu evidence dituliskan sebagai berikut :

Dimana :

$$
P(H \mid E, e)=\mathrm{P}(\mathrm{H} \mid \mathrm{E}) \frac{\mathrm{p}(\mathrm{e} \mid \mathrm{E} \cdot \mathrm{H})}{\mathrm{p}(\mathrm{e} \mid \mathrm{E})}
$$

e : evidence lama

$\mathrm{E} \quad$ : evidence baru

$\mathrm{P}(\mathrm{H} \mid \mathrm{E}, \mathrm{e}) \quad$ : probabilitas adanya hipotesa $\mathrm{H}$, jika muncul evidence baru $\mathrm{E}$ dari evidence lama $\mathrm{e}$

$\mathrm{P}(\mathrm{e} \mid \mathrm{E}, \mathrm{H}) \quad$ : probabilitas kaitan antara e dan $\mathrm{E}$ jika hipotesa $\mathrm{H}$ benar

$\mathrm{P}(\mathrm{e} \mid \mathrm{E}) \quad$ : probabilitas kaitan antara e dan $\mathrm{E}$ tanpa memandang hipotesa apapun

$\mathrm{P}(\mathrm{H} \mid \mathrm{E}) \quad$ : probabilitas hipotesa $\mathrm{H}$ jika terdapat evidence $\mathrm{E}$

\section{METODOLOGI PENELITIAN}

\subsection{Teknik Pengumpulan Data (Data Collecting)}

Beberapa teknik yang dilakukan dalam penelitian ini adalah sebagai berikut:

1. Observasi

Dalam observasi peneliti melakukan pra-riset terlebih dahulu untuk mencari masalah yang terjadi dalam mendiagnosa penyakit gastritis. Data yang digunakan dalam penelitian ini adalah data primer.

2. Wawancara

Teknik wawancara dilakukan untuk menggali informasi mengenai gejala - gejala dan jenis penyakit gastritis. Berdasarkan hasil wawancara yang dilakukan adalah data awal yang menjadi tolak ukur dalam menentukan penyakit gastritis. Berdasarkan hasil wawancara yang dilakukan adalah data awal yang menjadi tolak ukur dalam mendiagnosa penyakit gastritis:

\section{Data Penyakit}

Tabel 1 Data Penyakit gastritis

\begin{tabular}{|c|l|}
\hline N0. & \multicolumn{1}{|c|}{ Penyakit Gastritis Pada Lambung Manusia } \\
\hline 1 & Gastritis Akut \\
\hline 2 & Gastritis Kronis \\
\hline
\end{tabular}

\section{Data Gejala}

Tabel 2 Data gejala - Gejala Penyakit Gastritis

\begin{tabular}{|c|l|}
\hline No & \multicolumn{1}{c|}{ Nama Gejala } \\
\hline 1 & Mual \\
\hline 2 & Muntah \\
\hline 3 & Cegukan \\
\hline 4 & Sakit Kepala \\
\hline 5 & Kelesuan \\
\hline 6 & Mengalami anoreksia \\
\hline 7 & Berat badan menurun \\
\hline 8 & Muka Pucat \\
\hline 9 & Sesak nafas \\
\hline 10 & Diare \\
\hline 11 & Perut Sakit \\
\hline 12 & Perut Kembung \\
\hline
\end{tabular}




\begin{tabular}{|l|l|}
\hline 13 & Nyeri Ulu Hati \\
\hline 14 & Mengalami hematesis \\
\hline 15 & Mengalami melena \\
\hline
\end{tabular}

\section{Basis Pengetahuan}

Tabel 3 Basis Pengetahuan Gejala - Gejala Penyakit gastritis

\begin{tabular}{|c|c|c|c|}
\hline No & Gejala Atau Penyakit & Gastritis Akut & Gastritis Kronis \\
\hline 1 & Mual & $\checkmark$ & $\checkmark$ \\
\hline 2 & Muntah & $\checkmark$ & $\checkmark$ \\
\hline 3 & Cegukan & $\checkmark$ & $\checkmark$ \\
\hline 4 & Sakit Kepala & $\checkmark$ & $\checkmark$ \\
\hline 5 & Kelesuan & $\checkmark$ & $\checkmark$ \\
\hline 6 & Mengalami anoreksia & $\checkmark$ & $\checkmark$ \\
\hline 7 & Berat badan menurun & $\checkmark$ & $\checkmark$ \\
\hline 8 & Muka pucat & & $\checkmark$ \\
\hline 9 & Sesak nafas & & $\checkmark$ \\
\hline 10 & Diare & $\checkmark$ & \\
\hline 11 & Perut Sakit & $\checkmark$ & \\
\hline 12 & Perut Kembung & \\
\hline 13 & Nyeri Ulu Hati & $\checkmark$ \\
\hline 14 & Mengalami hematesis & $\checkmark$ & \\
\hline 15 & Mengalami melena & $\checkmark$ & $\checkmark$ \\
\hline
\end{tabular}

\subsection{Algoritma}

\section{Menjumlahkan Nilai Probabilitas}

Setelah nilai probabilitas sudah didapat, maka selanjutnya akan dijumlahkan nilai probabilitas tersebut. Berdasarkan data sampel baru yang bersumber dari tabel konsultasi yaitu sebagai berikut :

Tabel 4 Gejala Penyakit gastritis dan Nilai Gejalanya Berdaasarkan Sampel Konsultasi

\begin{tabular}{|c|c|c|}
\hline Kode Penyakit & Kode Gejala & Nilai Gejala \\
\hline \multirow{11}{*}{$\mathrm{P} 01$} & G001 & 0,5 \\
\hline & G002 & 0,6 \\
\hline & G003 & 0,5 \\
\hline & G004 & 0,6 \\
\hline & G005 & 0,6 \\
\hline & G006 & 0,7 \\
\hline & G007 & 0,7 \\
\hline & G008 & 0,7 \\
\hline & G010 & 0,8 \\
\hline & $\mathrm{G} 014$ & 0,8 \\
\hline & G015 & 0,8 \\
\hline \multirow{8}{*}{ P02 } & G001 & 0,5 \\
\hline & G002 & 0,6 \\
\hline & G003 & 0,5 \\
\hline & G004 & 0,6 \\
\hline & G006 & 0,7 \\
\hline & G007 & 0,7 \\
\hline & G008 & 0,7 \\
\hline & G009 & 0,8 \\
\hline
\end{tabular}




\begin{tabular}{|c|c|c|}
\cline { 2 - 3 } & G011 & 0,8 \\
\cline { 2 - 3 } & G012 & 0,8 \\
\hline G013 & 0,8 \\
\hline
\end{tabular}

$\sum_{G n}^{n} k=1=G 1+\cdots+G n$

1. $\mathrm{P} 001=$ Gastritis akut

$\mathrm{G} 001=\mathrm{P}\left(\mathrm{E} \mid \mathrm{H}_{1}\right)=0.5$

$\mathrm{G} 002=\mathrm{P}\left(\mathrm{E} \mid \mathrm{H}_{2}\right)=0.6$

$\mathrm{G} 003=\mathrm{P}\left(\mathrm{E} \mid \mathrm{H}_{3}\right)=0.5$

$\mathrm{G} 014=\mathrm{P}\left(\mathrm{E} \mid \mathrm{H}_{13}\right)=0.8$

$\mathrm{G} 015=\mathrm{P}\left(\mathrm{E} \mid \mathrm{H}_{13}\right)=0.8$

$\sum_{G .5}^{5} k=5=0.5+0.6+0.5+0.8+0.8=3.2$

2. $\mathrm{P} 002=$ Gastritis kronis

$\mathrm{G} 001=\mathrm{P}\left(\mathrm{E} \mid \mathrm{H}_{1}\right)=0.5$

$\mathrm{G} 002=\mathrm{P}\left(\mathrm{E} \mid \mathrm{H}_{2}\right)=0.6$

$\mathrm{G} 003=\mathrm{P}\left(\mathrm{E} \mid \mathrm{H}_{3}\right)=0.5$

$\mathrm{G} 013=\mathrm{P}\left(\mathrm{E} \mid \mathrm{H}_{13}\right)=0.8$

3.3.1.1

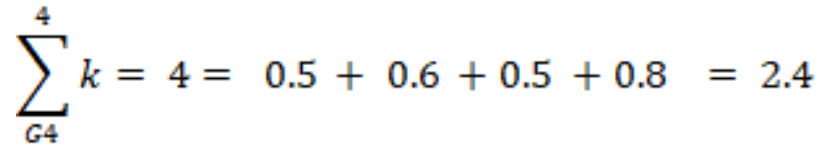

\section{Mencari nilai probabilitas}

hipotesa $\mathrm{H}$ tanpa memandang evidence

Mencari probabilitas hipotesa $\mathrm{H}$ tanpa memandang evidence dengan cara membagikan nilai probabilitas evidence awal dengan hasil penjumlahan probabilitas berdasarkan data sampel baru

$$
P\left(H_{i}\right)=\frac{P\left(E \mid H_{i}\right)}{\sum_{k}^{n}=n}
$$

1. $\mathrm{P} 001=$ Gastritis akut
a. $G 001=P\left(H_{1}\right)=\frac{0.5}{3.2}=0.16$
b. $G 002=P\left(H_{2}\right)=\frac{0.6}{3.2}=0.19$
c. $G 003=P\left(H_{3}\right)=\frac{0.5}{3.2}=0.16$
d. $G 014=P\left(H_{14}\right)=\frac{0.8}{3.2}=0.25$
e. $G 0015=P\left(H_{15}\right)=\frac{0.8}{3.2}=0.25$

2. $\mathrm{P} 002=$ Gastritis kronis
a. $G 001=P\left(H_{1}\right)=\frac{0.5}{2.4}=0.21$
b. $G 002=P\left(H_{2}\right)=\frac{0.6}{2.4}=0.25$ 

c. $G 003=P\left(H_{3}\right)=\frac{0.5}{2.4}=0.21$
d. $G 013=P\left(H_{13}\right)=\frac{0.8}{2.4}=0.33$

\subsubsection{Mencari nilai probabilitas hipotesa memandang evidence}

Mencari probabilitas hipotesis memandang evidence dengan cara mengalikan nilai probabilitas evidence awal dengan nilai probabilitas hipotesis tanpa memandang evidence dan menjumlahkan hasil perkalian bagi masing-masing hipotesis.

$$
\sum_{k=n}^{n}=P\left(H_{i}\right) * P\left(E \mid H_{i}\right)+\cdots+P\left(H_{i}\right) * P\left(E \mid H_{i}\right)
$$

1. $\mathrm{P} 001=$ Gastritis akut

$$
\begin{gathered}
\sum_{k=4}^{4}=(0.5 * 0.16)+(0.6 * 0.19)+(0.5 * 0.16)+(0.8 * 0.25)+(0.8 * 0.25) \\
=0.674
\end{gathered}
$$

2. $\mathrm{P} 002=$ Gastritis kronis

$$
\sum_{k=4}^{4}=(0.5 * 0.21)+(0.6 * 0.25)+(0.5 * 0.21)+(0.8 * 0.33)=0.624
$$

\subsubsection{Mencari nilai hipotesa $\mathrm{H}$ benar jika diberi evidence}

Nilai $\mathrm{P}\left(\mathrm{H}_{\mathrm{i}} \mid \mathrm{E}_{\mathrm{i}}\right)$ atau probabilitas hipotesis $\mathrm{H}$, dengan cara mengalikan hasil nilai probabilitas hipotesa tanpa memandang evidence dengan nilai probabilitas awal lalu dibagi dengan hasil probabilitas hipotesa dengan memandang evidence.

$$
P\left(H_{i} \mid E_{i}\right)=\frac{P\left(H_{i}\right) * P\left(E \mid H_{i}\right)}{\sum_{k}^{n}=n}
$$

1. $\mathrm{P} 001=$ Gastritis akut
a. $P\left(H_{1} \mid E\right)=\frac{0.5 * 0.16}{0.674}=0.1186$
b. $P\left(H_{2} \mid E\right)=\frac{0.6 * 0.19}{0.674}=0.1691$
c. $P\left(H_{3} \mid E\right)=\frac{0.5 * 0.16}{0.674}=0.1186$
d. $P\left(H_{14} \mid E\right)=\frac{0.8 * 0.25}{0.674}=0.2967$
e. $P\left(H_{15} \mid E\right)=\frac{0.8 * 0.25}{0.674}=0.2967$

2. $\mathrm{P} 002=$ Gastritis kronis
a. $P\left(H_{1} \mid E\right)=\frac{0.5 * 0.21}{0.624}=0.1682$ 

b. $P\left(H_{2} \mid E\right)=\frac{0.6 * 0.25}{0.624}=0.2403$
c. $P\left(H_{3} \mid E\right)=\frac{0.5 * 0.21}{0.624}=0.1682$
d. $P\left(H_{13} \mid E\right)=\frac{0.8 * 0.33}{0.624}=0.423$

\subsubsection{Mencari Nilai Kesimpulan}

Mencari nilai kesimpulan dari metode Teorema Bayes dengan cara mengalikan nilai pobabilitas evidence awal atau $P\left(E \mid H_{i}\right)$ dengan nilai hipotesa $H_{i}$ benar jika diberikan evidence $E$ atau $P\left(H_{i} \mid E\right)$ dan menjumlahkan perkalian.

$$
\sum_{K=1}^{n} \text { bayes }=P\left(E \mid H_{i}\right) * P\left(H_{i} \mid E_{i}\right) \ldots+P\left(E \mid H_{i}\right) * P\left(H_{i} \mid E_{i}\right)
$$

1. $\mathrm{P} 001=$ Gastritis akut

$$
\begin{aligned}
\sum_{K=5}^{5} \text { bayes }= & (0.5 * 0.1186)+(0.6 * 0.1691)+(0.5 * 0.1186)+(0.8 * 0.2967) \\
& +(0.8 * 0.2967)=0.69911
\end{aligned}
$$

2. $\mathrm{P} 002=$ Gastritis kronis

$$
\begin{aligned}
\sum_{K=4}^{4} \text { bayes }= & (0.5 * 0.1682)+(0.6 * 0.2403)+(0.5 * 0.1682)+(0.8 * 0.423) \\
& =0.65078
\end{aligned}
$$

Dari proses perhitungan menggunakan Teorema Bayes diatas, maka diketahui bahwa pasien yang melakukan konsultasi mengalami penyakit gastritis akut dengan nilai keyakinan 0.69911 atau $69,911 \%$

\subsection{Hasil}

1. Tampilan Halaman Menu Utama

Halaman menu utama merupakan tampilan halaman awal sistem untuk melakukan pengolahan data di dalam system pakar untuk mendiagnosa penyakit kanker dalam kandungan. Di bawah ini merupakan tampilan halaman menu utama adalah sebagai berikut : 


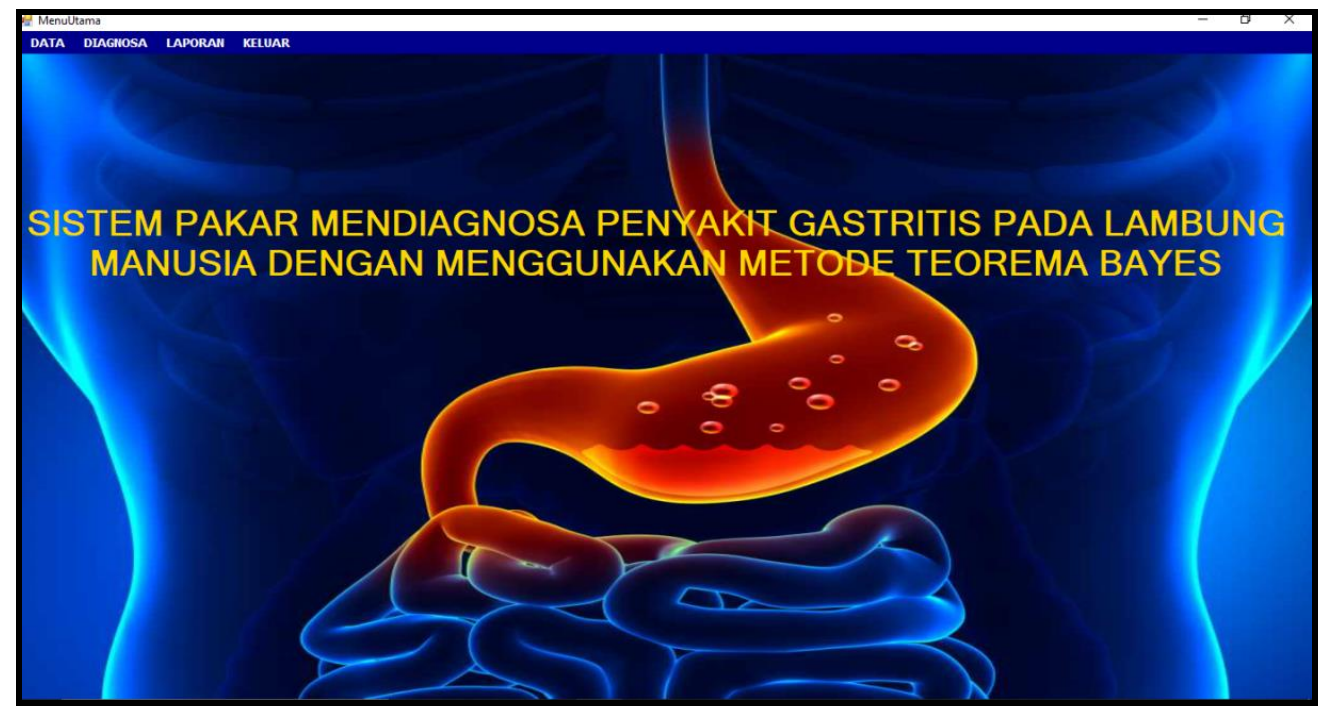

Gambar 1 Tampilan Halaman Menu Utama

2. Tampilan Halaman Form Proses

Berikut ini adalah tampilan Form Proses:

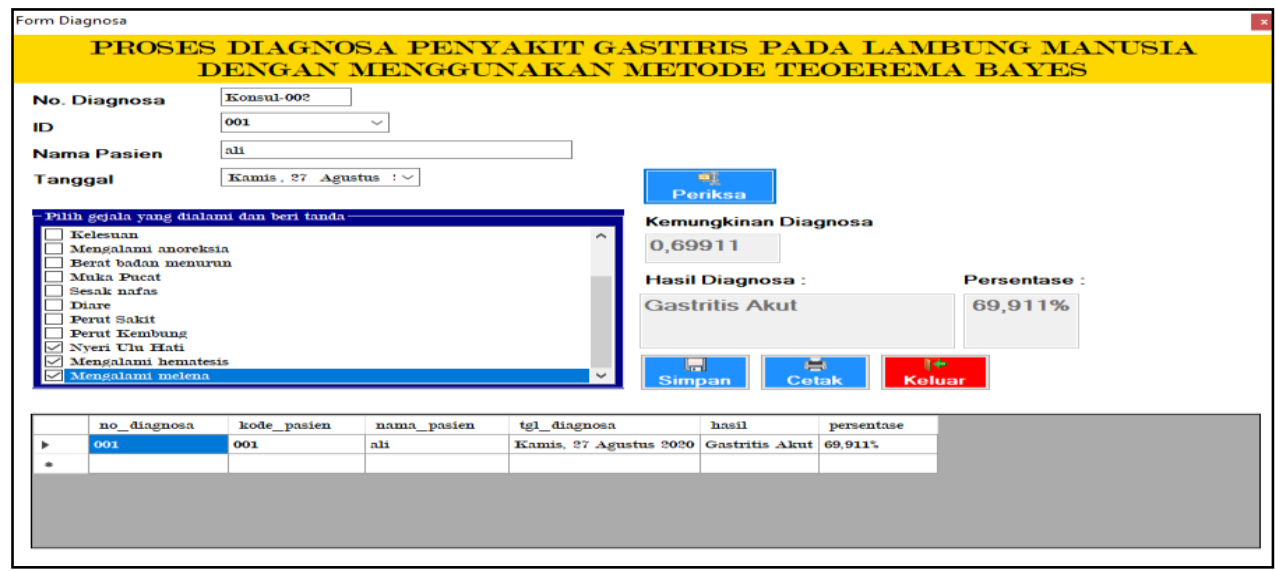

Gambar 3 Tampilan Form Proses

3. Tampilan form Laporan Hasil Perhitungan

Berikut ini adalah tampilan form Laporan Hasil Perhitungan:

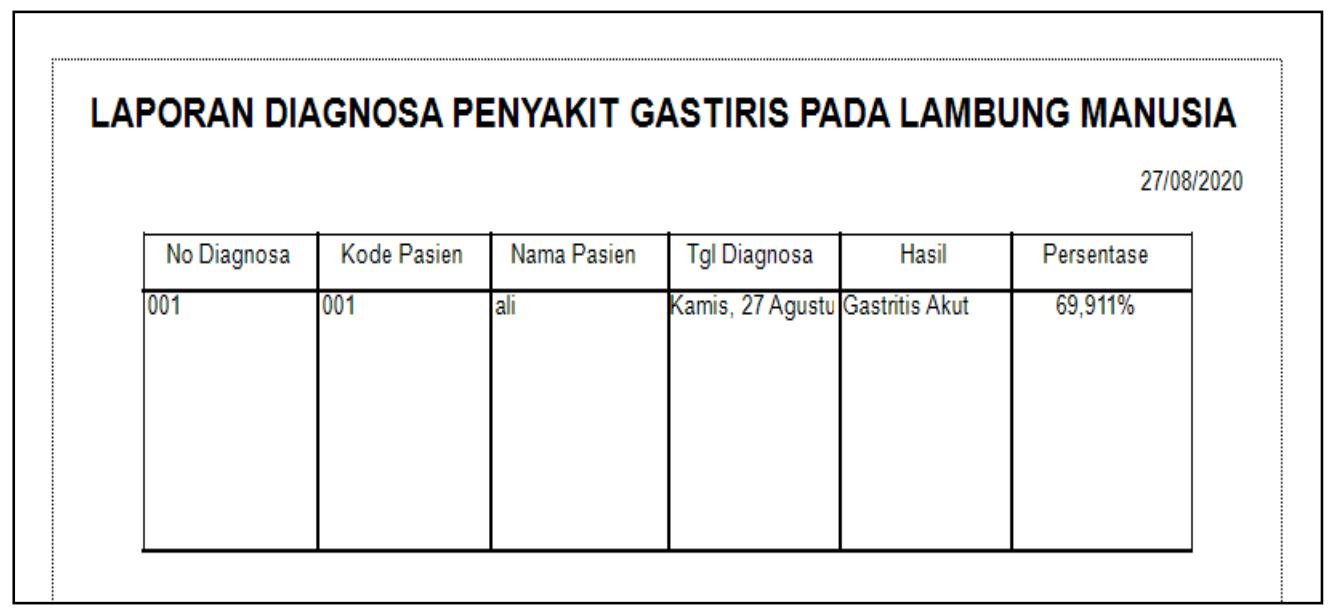

Gambar 3 Tampilan form Hasil Perhitunga 


\section{KESIMPULAN}

berikut:

Jadi kesimpulan yang dapat disimpulkan dari hasil diagnosa penyakit gastritis adalah sebagai

1. Analisis permasalahan untuk mendiagnosa penyakit gastiris pada lambung manusia menggunakan sebuah sistem kecerdasan buatan yaitu sistem pakar yang mengadopsi metode teorema bayes yang mampu mengenali jensi penyakit.

2. Proses mendiagnosa penyakit gastiris pada lambung manusia menggunakan metode teorema bayes diawali dengan proses penentuan penyakit dan gejala selanjutnya dilakukan proses perhitungan dengan memilih gejala - gejala yang dialami sehingga didapatkan nilai kesimpulan dari setiap penyakit untuk ditentukan yang terpilih berdasarkan nilai tertinggi.

3. Proses perancangan sistem diawali dengan penggambaran model menggunakan UML mulai skenario dari login, menu utama, data pasien, penyakit, gejala, proses perhitungan dan laporan, kemudian membuat databasenya, selanjutnya dirancang interface sistem yang kemudian dimasukkan kode program sesuai dengan metode teorema bayes yang digunakan.

4. Sistem dapat diimplementasikan pada aplikasi berbasis Dekstop Programming dengan menggunakan Microsoft visual basic 2010 yang mampu melakukan proses perhitungan dari mendiagnosa penyakit gastiris pada lambung manusia dengan menggunakan metode teorema bayes.

\section{REFERENSI}

[1] F. Eleanora, "BAHAYA PENYALAHGUNAAN NARKOBA SERTA USAHA PENCEGAHAN DAN PENANGGULANGANNYA (Suatu Tinjauan Teoritis),” J. Huk., vol. 25, no. 1, pp. 439452, 2011.

[2] Rahmiyati, "Strategi Pencegahan Narkoba Terhadap Remaja Oleh: Rahmiyati, S.Pd Abstrak," pp. 54-58.

[3] Desi Leha Kurniasih, "Sistem Pendukung Keputusan Pemilihan Laptop Dengan Metode Topsis," Pelita Inform. Budi Darma, vol. III, no. April, pp. 29-36, 2013.

[4] N. Y. L. Gaol, "Sistem Pakar Mendiagnosa Penyakit Tanaman Buah Citrus ( Lemon ) Mengggunakan Metode Certainty Factor,” J. SAINTIKOM (Jurnal Sains Manaj. Inform. dan Komputer), vol. 19, no. 1, pp. 1-10, 2020.

[5] M. R. Fadillah, B. Andika, and D. Saripurna, "Sistem Pakar Mendiagnosa Penyakit Dan Hama Penyerang Tanaman Bougenville Dengan Metode Teorema Bayes," J. SAINTIKOM (Jurnal Sains Manaj. Inform. dan Komputer), vol. 19, no. 1, pp. 88-99, 2020.

[6] T. Syahputra and W. R. Maya, "Implementasi Sistem Pakar Untuk Mengidentifikasi Pecandu Narkoba Menggunakan Metode Teorema Bayes," J. SAINTIKOM (Jurnal Sains Manaj. Inform. dan Komputer), vol. 18, no. 2, pp. 111-118, 2019. 